\title{
EUU, English for the Uomo Universale
}

Trends in British engineering degrees and possible consequences for EST teaching at universities throughout Europe

\section{Karl Springer}

\section{(2) OpenEdition}

1 Journals

Electronic version

URL: http://journals.openedition.org/asp/4332

DOI: $10.4000 /$ asp.4332

ISSN: 2108-6354

\section{Publisher}

Groupe d'étude et de recherche en anglais de spécialité

\section{Printed version}

Date of publication: 1 October 1993

Number of pages: 389-394

ISSN: 1246-8185

\section{Electronic reference}

Karl Springer, «EUU, English for the Uomo Universale», ASp [Online], 2 | 1993, Online since 07 March 2014, connection on 07 May 2019. URL : http://journals.openedition.org/asp/4332 ; DOI : 10.4000/ asp.4332

This text was automatically generated on 7 May 2019.

Tous droits réservés 


\section{EUU, English for the Uomo Universale}

Trends in British engineering degrees and possible consequences for EST teaching at universities throughout Europe

\section{Karl Springer}

\section{Introduction}

1 The university all-rounder is the pride of tutors and the most desirable property for employers throughout the British Isles. This almost cult-like status is paralleled only in other Anglo-Saxon countries, not in continental Europe. A student sacrificing social or sporting life to obtain a starred first in Britain is much more likely to earn the contempt of fellow students and tutors than their admiration; the ethos of the "good college man", and not only man, is far from moribund. A "sportsman's third" will almost guarantee a job on the "milk-round", as employers cite well-known phrases such as "rounded personality", "application", "perseverance" and "team spirit".

Indeed, the formation of the personality has always been indirectly promoted at British universities since a high degree of personal maturity is required to achieve a good degree. Engineering students are largely left to their own devices; after first year they are able to pick and choose many of their courses; there is little external pressure to study hard - the prevailing mood among university teachers is that the student should decide for her/ himself whether to study hard or not, so threats or any form of disciplining are rare; students are left to employ their time as they see fit, with the number of contact hours remaining low by French standards (in engineering 15-20 as against 38 at ESSTIN) and attendance compulsory only when you have missed the last couple of times; knowledge is increased by students following reading lists, or not increased as the case may be - it is a matter of initiative and priorities on the students' part. "Spoon-feeding", though it goes on, and is attested by virtually every German student on exchange, is still by far the greatest anathema in British tertiary circles. Some of the emphases above are noticeably different in the case of French engineering colleges. 
Despite the value upon, and indirect development of, the whole personality and social/ personal maturity, the university curriculum itself has contributed little to this or to any form of intellectual maturity beyond the subject of study. Talk of liberal arts for engineers would some years ago, if you were lucky, merely have provoked a wry smile, if you were unlucky, hysterical laughter. Equally limiting was the actual subject of study: whereas French engineering students would follow the baccalaureat with a degree in general engineering including the natural sciences and mathematics, or with the general scientific background of the école préparatoire and study at a specialised engineering college, their equivalents in England and Wales would normally specialise in three subjects from ages 16 to 18 and then usually in one branch of engineering for their university degree, such as civil, mechanical or electrical. (In part, of course, this specialisation is inevitable in a hothouse system which can turn out graduates of only twenty-one years of age, the youngest in Europe.) The few exceptions to the prevailing specialisation in British degrees have usually come about as a result of administrative and/or vocational considerations, as in the case of Politics, Philosophy and Economics at Oxford. In the 1980's some tertiary institutions, notably the polytechnics, developed a modular system, though the main effect of this was to increase the possible combinations of two, occasionally three, subjects rather than provide breadth itself.

\section{New Trends}

In Britain it was not until the eighties that engineers began to be seen as industrial managers of the future, indeed potential captains of industry, rather than obsessed boffins in white aprons with oily hands. At that time meritocratic trends in politics and society as a whole were in the process of, at the very least, weakening the old academic hierarchy, which had the humanities at the top of the tree, the pure sciences in the middle, and the engineering subjects for "secondary modern boys [sic]" at the bottom, and this tendency looks set to continue throughout the nineties.

In reaction to these trends, and in an attempt to provide a more liberal education, all engineering faculties today offer courses in business, management and marketing. The content of these courses themselves has over the years swollen so as to include subjects as diverse as communication, patent law, company law, behavioural studies, industrial psychology and personnel management. Engineers have become human engineers too. Courses or modules in engineering design or product development have also been instituted, with content such as industrial design, aesthetics and style, and ergonomics. More recently environmental engineering has been gaining ground, so that the trainee engineer is faced not only with measuring the efficiency of the filter system in a coalfired power station but also the ethical issues arising from the conflicting claims of costefficient technology and environment.

Thus engineering students are necessarily plunged into open-ended problem-solving with its vagaries and imponderables, undergo training in decision analysis and decisionmaking, learn the principles of compromise, and the necessity of value judgments and a coherent, reasoned set of views on life outside the laboratory. This "holistic" approach to engineering education would seem likely to make further advances: according to Terry Duggan, Dean of Engineering at Portsmouth University and Chairman of the 1992 World Conference on Engineering Education, 
the traditional subdivisions of the various branches of the engineering professions are being eroded rapidly, and the reasons for this are not difficult to explain. They stem from the ubiquity of the computer and the increased complexity of engineering systems, resulting in an increasing need for integrated engineers educated across disciplines [my underlining] and capable of exercising a systems approach to thinking and problem solving. (Duggan 1992a)

\section{Consequences for EST teaching at European universities}

7 The main concepts of relevance for EST teachers which arise from the trends described above are first the increasing variety and interdisciplinarity of British engineering degrees, which entail training students for language contexts lying well outside traditional scientific confines, and secondly, the open-ended nature of much of the new material, which will require a high level of discursive facility, both spoken and written, on the part of exchange students. The consequences of these trends for French institutions preparing students for exchange in Britain are thus considerable and may cause what are sometimes seen as the straightjackets of EST teaching to be removed.

8 A few teachers, and no few students, feel the constraint of EST itself, which may be the only English taught (though this is not totally without reason in terms of the relatively low English standards of students and the low number of contact hours supposed to suffice for a study period abroad); now a wider range of subject areas can, indeed should, be treated.

9 A second, related, constraint is that EST teachers are normally not scientists/engineers, are therefore rarely able to distance students in technical understanding, and therefore are dependent on topics with which students are already familiar, either from school, or earlier in their university course; while such topics are valuable, in particular for weaker students in making the acquisition of new language les gruelling, if it is only technical English that is provided for by the curriculum, the teacher will find it difficult to motivate students in terms of teaching content new to them, and a sense of dèjà vu might become commonplace; now students can be taught facts, processes and relationships they are wholly unfamiliar with.

There is a third constraint connected with oral communication, which can tend to be neglected since it is difficult to justify much time for this as there are hardly enough contact hours to deal with the absolute priorities of study skills in advance of the exchange. It can also be difficult to motivate students used to passivity to English at school and in other courses at university since, on the one hand, fluency exercises may seem to them childish and trivial in comparison to lines and lines of equations and, on the other, may seem of little benefit to their future study in Britain if the fluency is not immediately relevant to science. If teachers have paid less attention to speaking, they have done so reluctantly, not simply because it is one of the four core skills and because students will obviously need it to integrate into British culture and therefore derive maximum benefit from their stay, but also because it has continued students in their passivity. Now, however, in view of subjects like psychology and ergonomics, teachers will feel justified in employing time on fluency exercises and have ample reasons which will motivate their students; for the study period abroad will involve topics where there 
is no absolute truth, no right or wrong answer, but where mature and sophisticated debate is at a premium.

This leads to the elimination of a potential fourth constraint: neither time could be justified nor students motivated for a prolonged seminar discussion in which most students felt the desire and/or ability to participate. As a result of the increasing openendedness of the content of engineering degrees, the art of argument and seminar discussion, a closed book to French engineering students, must be actively taught and practised, together with functions such as how to agree and disagree and politeness formulae in general. (Similarly, written work can be enlivened: students must be trained not only in producing factual reports but also in discursive writing, whether it is an ergonomic consideration of the chair they are sitting on or weighing up the pros and cons of nuclear power and coming to a cogent conclusion without self-opinionatedness. Many students in a French engineering college will welcome the opportunity to include their own opinions and outlook on life, in effect themselves, in the work they produce.)

Finally, and perhaps most importantly, the diversification of an engineering degree at a partner university might provide some added leverage to traditional claims of English departments here for more curriculum time, allocation at present being hardly sufficient to prepare students for exchange.

Thus, trends in engineering departments in Britain constitute a "liberty" in the traditional sense of the "liberal arts" for those studying there. Yet it is also to be hoped that these trends can be exploited in EST teaching at French institutions in that they should necessarily lead to an increase in variety of content and range of skills taught, and to a reduction in constraints perceived by some teachers.

\section{BIBLIOGRAPHY}

Duggan, T.V. 1992a. "The changing nature of engineering education and the shape of things to come". Keynote address. In Duggan, T.V. (ed.), World Conference on Engineering Education, vol 1. Southampton (UK) and Boston (USA): Computational Mechanics Publications, 4-14.

Duggan, T.V. 1992. "Engineering education in Europe". IEEE Communications Magazine November, $38-43$.

Duggan, T.V. 1992. "Developing cross-cultural links in Engineering Higher Education". Unpublished paper.

\section{ABSTRACTS}

The curricula of British universities have until recently fought shy of the least tendency to the liberal arts, to a broadening of study topics, indeed to any despecialization. Engineering degrees with courses in business and management studies, languages, ergonomics and psychology however, are intended to provide a more general education in terms of structures and processes 
of thought; at the same time, these courses both preserve some relationship to the traditional working environment of engineers yet also prepare them for a role in industrial management. Such developments necessarily entail rethinking EST curricula at institutions in Europe providing language training for students who will study engineering on exchange in Britain.

Jusqu'à une époque récente, les universités britanniques ont toujours vu avec la plus grande circonspection toute velléité de rendre moins spécialisées les études et d'élargir les programmes vers les humanités. Actuellement, se développent des diplômes d'ingénieurs comprenant des enseignements de gestion et commerce, de langues, d'ergonomie et de psychologie ; cursus qui proposent un enseignement plus général en termes de processus de pensée, afin de mieux préparer les étudiants à leur futur rôle de responsables dans l'industrie. Cette évolution met les institutions européennes dans l'obligation de repenser les programmes d'anglais de spécialité et de technologie pour leurs futurs stagiaires en Grande-Bretagne.

\section{INDEX}

Mots-clés: anglais de spécialité, école d'ingénieur, programme d'enseignement

Keywords: curriculum, engineering college, EST

\section{AUTHOR}

KARL SPRINGER

ESSTIN, Université Nancy 1 